ISSN 1678-3921

Journal homepage: www.embrapa.br/pab

For manuscript submission and journal contents, access: www.scielo.br/pab

\section{Genetic evaluation models for post-weaning weight gain in a multibreed Angus-Nelore population}

\begin{abstract}
The objective of this work was to identify the most suitable model for the genetic evaluation of post-weaning weight gain in a multibreed AngusNelore population. Three models were tested using the Bayesian inference method: traditional animal model (M1), multibreed animal model without (M2) and with segregation (M3). The choice of the best model followed the criteria: number of parameters $(\mathrm{Np})$, deviance information criterion (DIC), conditional predictive ordinate (CPO), and deviance based on Bayes factors. Spearman's rank correlations were estimated for the top 10, 20, and $30 \%$ sires. M1 presented the highest values for all criteria, except for Np, and the lowest direct heritability estimate of $0.15 \pm 0.01$. The heritability estimates for M2 and M3 were higher and similar, being $0.29 \pm 0.02$ and $0.27 \pm 0.02$, respectively. M3 showed the lowest values for mean deviance, DIC, and CPO, being the best-fitting model among the three tested. Spearman's correlation between the predicted genetic values for the models ranged from 0.69 to 0.99 . The multibreed models are the most suitable for the genetic evaluation of multibreed populations, and M3 shows the best fit for the studied population.
\end{abstract}

Index terms: animal breeding, crossbreeding, dominance, epistatic losses, genetic parameters.

\section{Modelos de avaliação genética para ganho de peso pós-desmama em uma população multirracial de Angus-Nelore}

Resumo - O objetivo deste trabalho foi identificar o modelo mais adequado para avaliação genética do ganho de peso pós-desmama em uma população multirracial de Angus-Nelore. Foram testados três modelos com uso do método de inferência bayesiana: animal tradicional (M1), animal multirracial sem (M2) e com segregação (M3). A escolha do melhor modelo seguiu os critérios: número de parâmetros $(\mathrm{Np})$, critério de desvio de informação (CDI), predição condicional (PCO) e desvio com base nos fatores de Bayes. Foram estimadas as correlações de postos de Spearman para os 10, 20 e 30\% melhores touros. M1 apresentou os maiores valores para todos os critérios, exceto para $\mathrm{Np}$, e a menor estimativa de herdabilidade direta, de $0,15 \pm 0,01$. As estimativas de herdabilidade de M2 e M3 foram maiores e similares, de $0,29 \pm 0,02$ e $0,27 \pm 0,02$, respectivamente. M3 apresentou os menores valores para desvio-médio, CDI e PCO, tendo sido o modelo de melhor ajuste entre os três testados. A correlação de Spearman entre os valores genéticos previstos para os modelos variou de 0,69 a 0,99 . Os modelos multirraciais são mais adequados para a avaliação genética de populações multirraciais, e o M3 apresenta o melhor ajuste para a população estudada.

Termos para indexação: produção animal, cruzamento, dominância, perda epistática, parâmetros genéticos. 


\section{Introduction}

Crossbreeding is the mating method used to bring together desirable traits of different breeds, aiming to form a new breed or simply to explore the effects of heterosis. Between taurine and zebuine cattle, crossbreeding seeks to combine the meat productivity and quality of the first breed with the capacity for adaptation to subtropical regions of the second. Among the breeds used in Brazil with this purpose, Angus and Nelore stand out.

When assessing the growth traits of animals produced through crossbreeding in tropical environments, it is assumed that two sets of genes are acting: one related to growth potential and the other to adaptation (Pimentel et al., 2006). Therefore, the genetic analysis of a multibreed population requires the inclusion of additive genetic effects for each breed, heterozygosis (Cardoso et al., 2008; Williams et al., 2010), epistatic losses (Dias et al., 2011), and complementarity between the different breeds (Cardoso et al., 2008). However, the use of all these effects may lead to problems, such as models that are highly complex, with high computational requirements and convergence difficulties or even with low accuracy estimates.

Non-additive genetic effects are generally included as covariables in traditional models (Dias et al., 2011) to address these problems, which, at first glance, are reduced in the analysis by this procedure; however, this is not the most accurate way of evaluating animal populations originating from crossbreeding. To solve this issue, Cardoso \& Tempelman (2004) proposed a multibreed animal model that included additive and non-additive fixed genetic effects with random individual deviations, based on Lo et al. (1993), as a parsimonious and satisfactory alternative for genetic evaluations of composite populations.

As the total genetic merit of a crossbred animal is estimated from additive and non-additive genetic effects (Miller, 2010), it is important to correctly model genotypic means and genetic covariance between relatives. For this, it is necessary to take into account the particular genetic variability of each group, since the standards used to assess multibreed and purebred populations differ (Oliveira et al., 2010). In this context, the analysis of the different models and the correct choice of the one that best fits the data for the genetic evaluation of multibreed populations is the main decision to be made in breeding programs, allowing to obtain more accurate estimates and predictions.

The objective of this work was to identify the most suitable model for the genetic evaluation of postweaning weight gain in a multibreed Angus-Nelore population.

\section{Materials and Methods}

The database used was provided by the companies Gensys Consultores Associados $\mathrm{S} / \mathrm{S}$ and Natura Genetica Sul Americana and was composed of information obtained from 432,049 animals. To prepare the data to carry out the analyzes, contemporary groups were formed taking into account year and season of birth, sex (uncastrated male, castrated male, and female), farm of origin, and the feed management system to which the animals were subjected to. For the consistency of data, the following were discarded: contemporary groups with fewer than five animals; bulls with fewer than five offspring; and animals for which the post-weaning weight gain (PWG) was more than 3.5 standard deviations upwards or downwards in relation to the mean for the contemporary group to which the animal belonged. The connectability between these groups was assessed based on the total number of genetic ties, considering a minimum of 10 , through the AMC software (Roso \& Schenkel, 2006).

After data restriction, the information of 55,484 animals for PWG standardized for 345 days remained. These animals were sired by 37,577 dams and 1,073 sires, and were born between 1986 and 2015, being reared on 74 farms in different states of Brazil and in Paraguay. There were six distinct breed compositions (BC): $\mathrm{BC} 1$, Angus breed, totaling 13,507 animals; BC2, 3/4 Angus, 965 animals; $\mathrm{BC} 3$, 5/8 Angus, 34,511 animals; BC4, 9/16 Angus, 6,464 animals; BC5, 1/2 Angus, 31 animals; and BC6, 1/4 Angus, 6 animals.

The multibreed animal model used in the study was based on the hierarchical Bayesian model proposed by Cardoso \& Tempelman (2004). It makes specific genetic variance assumptions due to segregation between breeds, which correspond to the additional variance observed in the $F_{2}$ generation in relation to $F_{1}$ (Lo et al., 1993). The model is described as:

$$
\begin{aligned}
& \mathrm{y}_{\mathrm{ijk}}=\mu+\mathrm{CG}_{\mathrm{i}}+\beta_{\mathrm{IV}}\left(\mathrm{CA}_{\mathrm{j}}\right)+\beta_{\mathrm{IV}}\left(\mathrm{CA}_{\mathrm{j}}^{2}\right)+\beta_{\mathrm{A}}\left(\mathrm{f}_{\mathrm{k}}\right)+ \\
& \beta_{\mathrm{D}}\left(\delta_{\mathrm{k}}\right)+\beta_{\mathrm{AA}}\left(2\left[1-\mathrm{f}_{\mathrm{k}}\right] \mathrm{f}_{\mathrm{k}}\right)+\mathrm{u}_{\mathrm{k}}+\mathrm{e}_{\mathrm{ijk}}
\end{aligned}
$$


where $\mathrm{y}_{\mathrm{ijk}}$ is the PWG recorded for the $\mathrm{i}^{\text {th }}$ animal of the $i^{\text {th }}$ contemporary group; $\mu$ is a constant; $\mathrm{CG}_{\mathrm{i}}$ is the effect of the $\mathrm{i}^{\text {th }}$ contemporary group $(\mathrm{i}=1,2, \ldots$, 1,958), such that $\mathrm{CGi} \sim \mathrm{N}\left(0, \sigma_{\mathrm{CG}}^{2}\right)$ for all $\mathrm{i} ; \beta$ 's are the regression coefficients associated with the cow's age (CA) in years $3 \leq \mathrm{CA} \leq 15$; $\mathrm{A}$ is the additive fixed effect of the Angus breed; $\mathrm{D}$ is the Nelore-Angus dominance effect; $A A$ is the Nelore-Angus additive $x$ additive epistatic effect; $f_{k}$ is the expected proportion of Angus genes in animal k; $\delta_{\mathrm{k}}$ is the coefficient of heterozygosity obtained from the paternal $(\mathrm{P})$ and maternal (M) generations, considering the likelihood that one of the alleles would originate from the Nelore breed $\left(f_{k_{N}}\right)$ and the other from the Angus breed $\left(f_{k_{A}}\right)$ for a randomly chosen locus from individual $\mathrm{k}$, by

$$
\left(\delta_{\mathrm{k}}=\mathrm{f}_{\left(\mathrm{k}_{\mathrm{A}}\right)}^{\mathrm{P}} \mathrm{f}_{\left(\mathrm{k}_{\mathrm{N}}\right)}^{\mathrm{M}}+\mathrm{f}_{\left(\mathrm{k}_{\mathrm{N}}\right)}^{\mathrm{P}} \mathrm{f}_{\left(\mathrm{k}_{\mathrm{A}}\right)}^{\mathrm{M}}\right) ;
$$

$2\left[1-f_{k}\right] f_{k}$ is the additive $x$ additive epistatic coefficient for animal $\mathrm{k}$, based on the definition of losses due to recombination given by Kinghorn (1980); $u_{k}$ is the additive genetic effect of animal $\mathrm{k}$, assuming that

$$
\mathrm{u}=\left\{\mathrm{u}_{\mathrm{k}}\right\}_{\mathrm{k}=1}^{87,737} \sim \mathrm{N}(0, \mathrm{G}),
$$

with $\mathrm{G}$ being the matrix of multibreed genetic (co) variance, which is a function of specific additive genetic variances according to breed $-\sigma_{\mathrm{g}(\mathrm{A})}^{2}$ for Angus and $\sigma_{g(\mathrm{~N})}^{2}$ for Nelore -, of the variance of segregation between both breeds $\left(\sigma_{\mathrm{S}(12)}^{2}\right)$, and of the additive kinship between animals; and $\mathrm{e}_{\mathrm{ijk}}$ is the residual error with normal homoscedastic distribution $\left(\mathrm{e}_{\mathrm{ijk}} \sim \mathrm{N}\left(0, \sigma_{\mathrm{e}}^{2}\right)\right)$ for combinations $\mathrm{i}, \mathrm{j}$, and $\mathrm{k}$.

Three different models were used to estimate variance components and for genetic evaluation: the traditional animal model (M1), which is commonly adopted in genetic improvement programs, but does not take into account the additive genetic variances between breeds $\left(\sigma_{g(\mathrm{~A})}^{2}=\sigma_{\mathrm{g}(\mathrm{N})}^{2}\right)$ and considers the variance of segregation to be the same as for a purebred population, i.e., equal to zero $\left(\sigma_{\mathrm{S}(\mathrm{AN})}^{2}=0\right)$; the multibreed animal model without segregation (M2), which takes into consideration the differences in additive genetic variance between the two breeds, but assumes that the variance of segregation between them is equal to zero $\left(\sigma_{\mathrm{S}(\mathrm{AN})}^{2}=0\right)$; and the multibreed animal model with segregation (M3), which considers that the additive genetic variances between the breeds are different and that there is segregation between them $\left(\sigma_{\mathrm{S}(\mathrm{AN})}^{2} \neq 0\right)$. Consequently, the direct heritability $\left(\mathrm{h}_{\mathrm{a}}^{2}\right)$ of PWG for M1, M2, and M3 was estimated as:

$$
\begin{aligned}
& \mathrm{h}_{\mathrm{a}}^{2}=\frac{\sigma_{\mathrm{g}}^{2}}{\sigma_{\mathrm{g}}^{2}+\sigma_{\mathrm{e}}^{2}}, \mathrm{~h}_{\mathrm{a}}^{2}=\frac{\sigma_{\mathrm{g}(\mathrm{A})}^{2}+\sigma_{\mathrm{g}(\mathrm{N})}^{2}}{\sigma_{\mathrm{g}(\mathrm{A})}^{2}+\sigma_{g(\mathrm{~N})}^{2}+\sigma_{\mathrm{e}}^{2}}, \text { and } \\
& \mathrm{h}_{\mathrm{a}}^{2}=\frac{\sigma_{\mathrm{g}(\mathrm{A})}^{2}+\sigma_{\mathrm{g}(\mathrm{N})}^{2}+\sigma_{\mathrm{S}(\mathrm{AN})}^{2}}{\sigma_{g(\mathrm{~A})}^{2}+\sigma_{g(\mathrm{~N})}^{2}+\sigma_{\mathrm{S}(\mathrm{AN})}^{2}+\sigma_{\mathrm{e}}^{2}},
\end{aligned}
$$

respectively, where $\sigma_{\mathrm{g}}^{2}$ is the additive genetic variance of the breed, with (A) representing Angus and (N), Nelore; $\sigma_{\mathrm{s}_{(\mathrm{AN})}}^{2}$ is the variance of segregation between breeds; and $\sigma_{\mathrm{e}}^{2}$ is the residual variance.

The components of (co)variance were estimated by Bayesian inferences based on the Monte Carlo method via Markov chains. There were 510,000 iterations; the first 10,000 were discarded and a resampling interval of 50 iterations was used, totaling 10,000 samples. The software used was Intergen, version 1.3 (Cardoso et al., 2016). The convergence of the Markov chain was ascertained through the criteria of Heidelberger \& Welch (1983) and Geweke (1992), using the Bayesian output analysis library, version 2.15.2 (Smith, 2007), in the R software (R Core Team, 2013).

To choose the best model, the criteria used were: deviance information criterion (DIC) (Spiegelhalter et al., 2002), deviance based on the conditional predictive ordinate (CPO) (Gelfand, 1996), and deviance based on Bayes factors (BF) (Newton \& Raftery, 1994). Lower values indicate a better fit, considering the degree of separation of the evaluated model from a hypothetical model of perfect fit (Ambrosini et al., 2014). Spearman's rank correlations were also calculated based on the estimated genetic values for PWG from the three models, for all sires (1,073 individuals) and separately for the top 10, 20, and $30 \%$.

\section{Results and Discussion}

The M1 model presented the highest values for all chosen criteria, showing the worst fit (Table 1). This result indicates that not considering the genetic variation between breeds can cause modeling problems for PWG (Cardoso \& Tempelman, 2004; Oliveira et al., 2010). When comparing the two multibreed models, M3 $\left(\sigma_{\mathrm{S}(\mathrm{AN})}^{2} \neq 0\right)$ presented a better fit regarding deviance, DIC and $\mathrm{CPO}$, but $\mathrm{M} 2$ was slightly better regarding $\mathrm{BF}$. The small difference observed in the BF criterion indicated that it was more conservative, favoring the model with 
fewer parameters, i.e., M2. In addition to the parameters in M2, M3 also included number of parameters, which was expected to penalize it (Kass \& Raftery, 1995). Despite this, M3 showed to be more accurate for the genetic evaluation of the studied population.

The estimated solutions for the additive genetic effects of the Angus breed, dominance, and epistasis showed the same behavior in the three models, indicating that the productive potential for PWG tended to increase as the proportion of Angus genes increased (Table 2). In addition, in all models, the mean PWG increased with the increase in the genetic proportion of the Angus breed. This result shows the superiority of the Angus breed, which stands out for having a greater precocity of growth and termination than Zebu. This may be related to the history of selection of the Angus breed, which is known and selected for precocity of growth, whereas the Nelore breed has only been recently selected for growth (Toral

Table 1. Criteria for choosing the best fitting model for the trait post-weaning weight gain (PWG), when comparing a traditional animal model (M1), a multibreed animal model without segregation (M2), and a multibreed animal model with segregation $(\mathrm{M} 3)^{(1)}$.

\begin{tabular}{lccccc}
\hline Model & $\begin{array}{c}\text { Deviance } \\
\text { mean }\end{array}$ & Np & DIC & CPO & BF \\
\hline M1 & $537,871.4$ & $18,844.1$ & $556,715.5$ & $538,432.1$ & $529,666.5$ \\
& $\left(3^{\text {rd }}\right)$ & $\left(1^{\text {st }}\right)$ & $\left(3^{\text {rd }}\right)$ & $\left(3^{\text {rd }}\right)$ & $\left(3^{\text {rd }}\right)$ \\
M2 & $537,598.1$ & $19,050.6$ & $556,648.6$ & $538,412.3$ & $529,104.5$ \\
& $\left(2^{\text {nd }}\right)$ & $\left(2^{\text {nd }}\right)$ & $\left(2^{\text {nd }}\right)$ & $\left(2^{\text {nd }}\right)$ & $\left(1^{\text {st }}\right)$ \\
M3 & $537,043.6$ & $19,485.3$ & $556,528.9$ & $538,406.1$ & $529,168.9$ \\
& $\left(1^{\text {st }}\right)$ & $\left(3^{\text {rd }}\right)$ & $\left(1^{\text {st }}\right)$ & $\left(1^{\text {st }}\right)$ & $\left(2^{\text {nd }}\right)$ \\
\hline
\end{tabular}

(1) $\mathrm{Np}$, number of parameters; DIC, deviance information criterion; CPO, deviance based on the conditional predictive ordinate; and $\mathrm{BF}$, Bayes factor. $1^{\text {st }}, 2^{\text {nd }}$, and $3^{\text {rd }}$, indicate the ranking of the best fits.

Table 2. Mean genetic effects and standard deviations estimated by a traditional animal model (M1), a multibreed animal model without segregation (M2), and a multibreed animal model with segregation (M3) for the trait postweaning weight gain from weaning to yearling $(\mathrm{kg})$.

\begin{tabular}{lccc}
\hline \multirow{2}{*}{ Effect } & \multicolumn{3}{c}{ Model } \\
\cline { 2 - 4 } & M1 & M2 & M3 \\
\hline Additive & $25.13 \pm 11.57$ & $25.74 \pm 12.55$ & $25.94 \pm 11.37$ \\
Dominance & $61.53 \pm 3.26$ & $61.71 \pm 3.17$ & $61.60 \pm 3.16$ \\
Epistasis & $-37.68 \pm 11.98$ & $-37.21 \pm 12.67$ & $-37.09 \pm 11.35$ \\
\hline
\end{tabular}

et al., 2012), not having been subjected to systematic selection processes in its location of origin.

According to Elzo \& Wakeman (1998), estimates for additive genetic effects are commonly used to determine expected progeny differences and to classify animals in purebred populations. However, the results obtained in the present study showed that the same does not apply to multibreed populations, because of the observed favorable dominance effect on performance and the adverse one of the additive effect $\times$ interaction (epistatic loss) on PWG. Therefore, despite being non-additive, these effects are also of interest and may influence the expected differences in the progeny of multibreed animals (Lopes et al., 2010; Bertoli et al., 2015). Bueno et al. (2012) highlighted that these effects are generally difficult to estimate, mainly due to multicollinearity. For this reason, most genetic evaluation systems only take into account the additive genetic effects in the model, even for multibreed populations.

Table 3. A posteriori variances for post-weaning weight gain from weaning to yearling $\left(\mathrm{kg}^{2}\right)$, estimated by a traditional animal model (M1), a multibreed animal model without segregation (M2), and a multibreed animal model with segregation (M3).

\begin{tabular}{|c|c|c|c|}
\hline Variance $^{(1)}$ & Mean \pm SD & Mode & $95 \% \mathrm{CI}$ \\
\hline & \multicolumn{3}{|c|}{ M1 } \\
\hline$\sigma_{6}^{2}$ & $136.25 \pm 11.45$ & 136.02 & $114.02-159.35$ \\
\hline \multirow[t]{2}{*}{$\sigma_{c}^{2}$} & $785.55 \pm 10.06$ & 787.26 & $765.48-805.32$ \\
\hline & \multicolumn{3}{|c|}{ M2 } \\
\hline$\sigma_{g(\mathrm{~A})}^{2}$ & $109.42 \pm 12.61$ & 106.60 & $85.91-135.21$ \\
\hline$\sigma_{g(N)}^{2}$ & $216.04 \pm 28.09$ & 215.64 & $160.77-272.27$ \\
\hline \multirow[t]{2}{*}{$\sigma_{c}^{2}$} & $781.73 \pm 9.74$ & 783.20 & $762.13-800.16$ \\
\hline & \multicolumn{3}{|c|}{ M3 } \\
\hline$\sigma_{\mathrm{g}(\mathrm{A})}^{2}$ & $114.66 \pm 13.39$ & 113.39 & $89.61-142.42$ \\
\hline$\sigma_{g(N)}^{2}$ & $183.21 \pm 32.74$ & 177.56 & $118.14-247.46$ \\
\hline$\sigma_{\mathrm{s}_{(\mathrm{AN})}}^{2}$ & $20.53 \pm 11.83$ & 11.16 & $5.38-49.12$ \\
\hline$\sigma_{\mathrm{e}}^{2}$ & $774.20 \pm 11.15$ & 774.98 & $751.53-795.16$ \\
\hline
\end{tabular}


A lower additive genetic variance a posteriori was observed when M1 $\left(\sigma_{0}^{2}\right)$ was used (Table 3). This may be due to the fact that the traditional animal model does not take genetic variance in breeds into account in populations produced through crossbreeding. Peters et al. (2014) found that the additive genetic variance estimated through the traditional animal model was approximately 2.16 times lower than of that from a multibreed model.

The posteriori means for $\sigma_{i}^{2}$ estimated by the M2 and M3 models were similar, with values within the $95 \%$ confidence interval. The means obtained through these two models for the Nelore breed $\left(\sigma_{g(\mathrm{~N})}^{2}\right)$ were approximately twice the magnitude of those obtained for the Angus breed $\left(\sigma_{g(\mathrm{~A})}^{2}\right)$. This differed from the findings of Oliveira et al. (2010), who reported variance estimates for the Angus breed 2.3 times greater than those for the Nelore breed, which they attributed to the greater expected proportion of 63.14\% Angus genes in the studied population. However, in the present study, although the proportion of Angus genes was greater, i.e., $68.87 \%$, the variance for the Nelore breed was also greater. It should be noted that, in general, the Nelore breed shows great genetic variation, which can possibly be explained by the genetic differences between its herds and by the length of time in which selection has been pursued for this breed (Farah et al., 2011; Toral et al., 2012).

The variation attributed to segregation between breeds measures the extent to which the additive genetic variance is greater in the new generation than in the previous one (Lo et al., 1993). This variance can be explained by the segregation that occurs in the formation of the gametes in the paternal generation, which will form the zygotes of the new generation. In the present study, the genetic variance attributed to segregation between breeds represented 17.9 and $11.2 \%$ of the estimated genetic variance for the Angus and Nelore breeds, respectively, being higher than the values reported by Elzo \& Wakeman (1998) and Oliveira et al. (2010).

The direct heritability $\left(\mathrm{h}_{\mathrm{a}}^{2}\right)$ for PWG (Figure 1) estimated through M1 was $0.15 \pm 0.01$. However, the estimates obtained through the M2 and M3 multibreed models were higher and similar to each other: $0.29 \pm 0.02$ and $0.27 \pm 0.02$, respectively. These estimates are

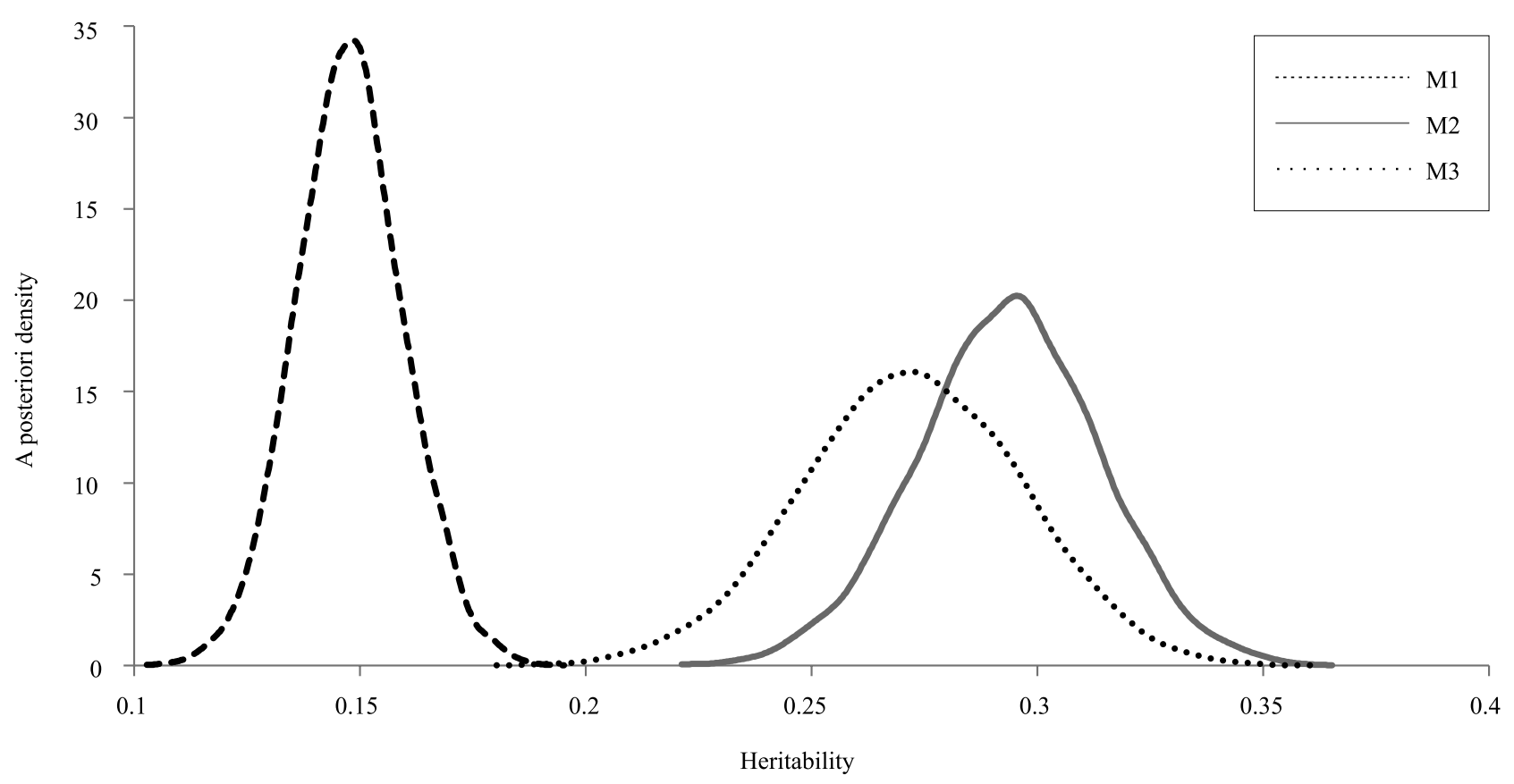

Figure 1. Direct heritability estimates for post-weaning weight gain $(\mathrm{kg})$ by a traditional animal model (M1), a multibreed animal model without segregation (M2), and a multibreed animal model with segregation (M3). 
indicative that additive genetic variability is needed to achieve genetic gains for the PWG trait. Despite the complexity of multibreed population structures, analyses based on multibreed models provide reliable inferences on the components of the additive genetic variance of this population, which is in alignment with Pedrosa et al. (2014) and Oliveira et al. (2010).

Spearman's rank correlations between the genetic values predicted by the three models were high, considering the total number of sires evaluated $(1,073$ individuals) (Table 4). When the sires were grouped as the top 10,20 , and $30 \%$, the correlations between the genetic values predicted by the multibreed models and by M1 decreased. For the top $10 \%$, the correlation between the genetic values predicted by M1 and those predicted by M2 and M3 were 0.93 and 0.94 , respectively. For the top 20 and $30 \%$, the correlations were lower, ranging from 0.69 to 0.81 . The classification of sires by M1 and by M2 and M3 differed from that obtained in the studies of Oliveira et al. (2010) and Cardoso \& Tempelman (2004).

The correlations between the genetic values predicted by multibreed models, however, were high, ranging from 0.93 to 0.98 for all classifications evaluated (top 10, 20, and 30\%); therefore, there was no change in how the sires were classified. According to Van Melis et al. (2003), it is interesting for breeders that the breeding animals be properly evaluated and ordered to maximize the genetic progress in the herd, as well as to increase profits from the activity.

The dispersion of the predicted values should lower variation among the top $10 \%$ sires. Considering the top 20 and $30 \%$, the differences between the ranking of breeding values were greater, especially when M1 was used (Figure 2). By this variation, it may be inferred that the animals selected as superior by the

Table 4. Spearman's rank correlation for breeding values for the trait post-weaning weight gain (PWG) obtained by a traditional animal model (M1), a multibreed animal model without segregation (M2), and a multibreed animal model with segregation (M3).

\begin{tabular}{lcccc}
\hline \multirow{2}{*}{ Model } & \multicolumn{4}{c}{ Sire } \\
\cline { 2 - 5 } & All sires & Top 10\% & Top 20\% & Top 30\% \\
\hline M1 versus M2 & 0.997 & 0.932 & 0.695 & 0.688 \\
M1 versus M3 & 0.998 & 0.942 & 0.792 & 0.815 \\
M2 versus M3 & 0.999 & 0.981 & 0.933 & 0.939 \\
\hline
\end{tabular}
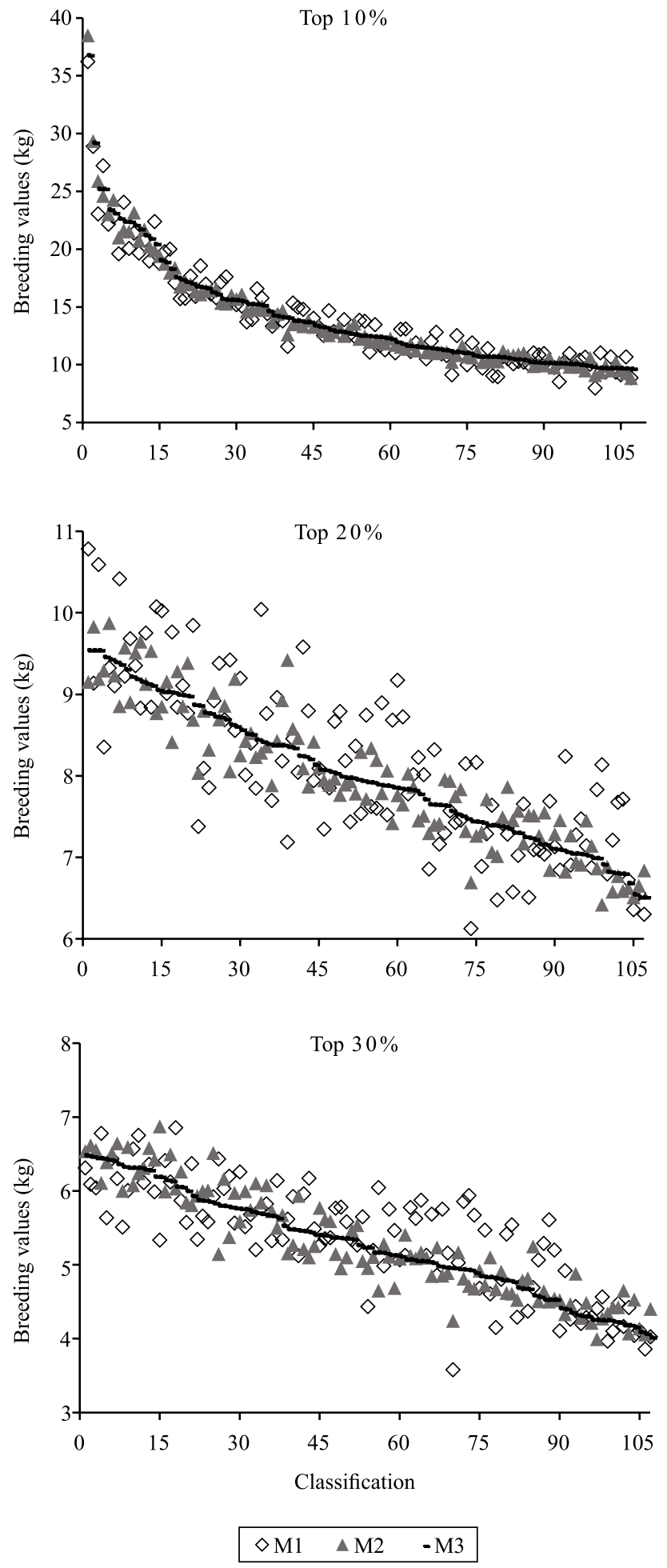

Figure 2. Breeding values predicted for post-weaning weight gain $(\mathrm{kg})$ by a traditional animal model (M1), a multibreed animal model without segregation (M2), and a multibreed animal model with segregation (M3) for sires classified as top 10 (A), 20 (B), and 30\% (C). 
traditional animal model are not necessarily the same as those by multibreed models. According to Newman et al. (2002), the estimates for genetic values and comparisons of crossbred sires may be less accurate, indicating that the precision of such estimates depends on model adjustment factors. These differences have a major influence on the commercial value of the semen from these animals, especially from high-ranking ones (Araújo et al., 2011). Therefore, the greatest impact from choosing the best model is on the classification of animals that are considered elite.

\section{Conclusions}

1. Multibreed models present better adjustment of performance data for the genetic evaluation of the trait post-weaning weight gain in multibreed AngusNelore populations, and the multibreed model with segregation is the most accurate.

2. The use of the multibreed model in the estimation of parameters and in the genetic evaluation of multibreed Angus-Nelore populations tends to increase genetic progress.

\section{Acknowledgments}

To Coordenação de Aperfeiçoamento de Pessoal de Nível Superior (Capes), for a doctoral scholarship to the first author.

\section{References}

AMBROSINI, D.P.; CARNEIRO, P.L.S.; BRACCINI NETO, J.; MARTINS FILHO, R.; AMARAL, R. dos S.; CARDOSO, F.F.; MALHADO, C.H.M. Reaction norms models in the adjusted weight at 550 days of age for Polled Nellore cattle in Northeast Brazil. Revista Brasileira de Zootecnia, v.43, p.351-357, 2014. DOI: https//doi.org/10.1590/S1516-35982014000700002.

ARAÚJO, C.V. de; BITTENCOURT, T.C.B. dos S.C. de; ARAÚJO, S.I.; LÔBO, R.B.; BEZERRA, L.A.F. Estudo da heterogeneidade de variâncias na avaliação genética de bovinos de corte da raça Nelore. Revista Brasileira de Zootecnia, v.40, p.1902-1908, 2011. DOI: https//doi.org/10.1590/S1516-35982011000900009.

BERTOLI, C.D.; BRACCINI, J.; MCMANUS, C.; COBUCI, J.A.; KERN, E.L.; PICCOLI, M.L.; SCHENKEL, F.; ROSO, V. Modeling breed additive and non-additive genetic effects using a Angus x Nellore crossbred population. Livestock Science, v.176, p.1-13, 2015. DOI: https//doi.org/10.1016/j.livsci.2015.03.020.

BUENO, R.S.; TORRES, R. de A.; FERRAZ, J.B.S.; LOPES, P.S.; ELER, J.P.; MOURÃO, G.B.; SILVA, M. de A. e; MATTOS, E.C. de. Métodos de estimação de efeitos genéticos não-aditivos para características de peso e perímetro escrotal em bovinos de corte mestiços. Revista Brasileira de Zootecnia, v.41, p.1140-1145, 2012. DOI: https//doi.org/10.1590/S1516-35982012000500009.

CARDOSO, F.F.; JUNQUEIRA, V.S.; MOTA, R.R. Soluções computacionais para a predição de valores genéticos em animais de produção: manual da versão 1.3 do Programa Intergen. Bagé: Embrapa Pecuária Sul, 2016. 28p.

CARDOSO, F.F.; TEMPELMAN, R.J. Hierarchical Bayes multiple-breed inference with an application to genetic evaluation of a Nelore-Hereford population. Journal of Animal Science, v.82, p.1589-1601, 2004. DOI: https//doi.org/10.2527/2004.8261589x.

CARDOSO, V.; QUEIROZ, S.A. de; FRIES, L.A. Estimativas de efeitos genotípicos sobre os desempenhos pré e pós-desmama de populações Hereford $x$ Nelore. Revista Brasileira de Zootecnia, p.1763-1773, 2008. DOI: https//doi.org/10.1590/S151635982008001000008 .

DIAS, R.A.P.; PETRINI, J.; FERRAZ, J.B.S.; ELER, J.P.; BUENO, R.S.; COSTA, A.L.L. da; MOURÃO, G.B. Multicollinearity in genetic effects for weaning weight in a beef cattle composite population. Livestock Science, v.142, p.188-194, 2011. DOI: https://doi.org/10.1016/j.livsci.2011.07.016.

ELZO, M.A.; WAKEMAN, D.L. Covariance components and prediction for additive and nonadditive preweaning growth genetic effects in an Angus-Brahman multibreed herd. Journal of Animal Science, v.76, p.1290-1302, 1998. DOI: https://doi. org/10.2527/1998.7651290x.

FARAH, M.M.; GARCIA, D.A.; CRUZ, V.A.R.; MEIRA, C.T.; PEREIRA, I.G.; PIRES, A. V; GONÇALVES, F.M. Avaliação genética para peso corporal em um rebanho Nelore. Arquivo Brasileiro de Medicina Veterinária e Zootecnia, v.63, p.158164, 2011.

GELFAND, A.E. Model determination using samplingbased methods. In: GILKS, W.R.; RICHARDSON, S.; SPIEGELHALTER, D.J. (Ed.). Markov chain Monte Carlo in practice: interdisciplinary statistics. Boca Raton: Chapman \& Hall/CRC, 1996. p.145-161.

GEWEKE, J. Evaluating the accuracy of sampling-based approaches to the calculation of posterior moments. In: BERNARDO, J.M.; BERGER, J.O.; DAWID, A.P.; SMITH, A.F.M. (Ed.). Bayesian statistics 4. Oxford: Oxford University Press, 1992.

HEIDELBERGER, P.; WELCH, P.D. Simulation run length control in the presence of an initial transient. Operations Research, v.31, p.1109-1144, 1983. DOI: https://doi.org/10.1287/ opre.31.6.1109.

KASS, R.E.; RAFTERY, A.E. Bayes factors. Journal of the American Statistical Association, v.90, p.773-795, 1995.

KINGHORN, B. The expression of "Recombination Loss" in quantitative traits. Zeitschrift Fur Tierzuchtung Und Zuchtungsbiologie, v.97, p.138-143, 1980. DOI: https://doi. org/10.1111/j.1439-0388.1980.tb00919.x.

LO, L.L.; FERNANDO, R.L.; GROSSMAN, M. Covariance between relatives in multibreed populations: additive model. 
Theoretical and Applied Genetics, v.87, p.423-430, 1993. DOI: https://doi.org/10.1007/BF00215087.

LOPES, J.S.; RORATO, P.R.N.; WEBER, T.; ARAÚJO, R.O.; DORNELLES, M.A.; COMIN, J.G. Avaliação do desempenho na pós-desmama para uma população bovina multirracial Aberdeen Angus x Nelore utilizando-se diferentes modelos genéticos. Arquivo Brasileiro de Medicina Veterinária e Zootecnia, v.62, p.1439-1447, 2010. DOI: https://doi.org/10.1590/S010209352010000600021.

MILLER, S. Genetic improvement of beef cattle through opportunities in genomics. Revista Brasileira de Zootecnia, v.39, p.247-255, 2010. DOI: https://doi.org/10.1590/S151635982010001300027.

NEWMAN, S.; REVERTER, A.; JOHNSTON, D.J. Purebredcrossbred performance and genetic evaluation of postweaning growth and carcass traits in Bos indicus $\times$ Bos taurus crosses in Australia. Journal of Animal Science, v.80, p.1801-1808, 2002. DOI: https://doi.org/10.2527/2002.8071801x.

NEWTON, M.A.; RAFTERY, A.E. Approximate Bayesian inference with the weighted likelihood bootstrap. Journal of the Royal Statistical Society. Series B (Methodological), v.56, p.348, 1994.

OLIVEIRA, M.M. de; CARDOSO, F.F.; OSÓRIO, J.C. da S. Componentes de variância e parâmetros genéticos em uma população multirracial Nelore-Angus sob enfoque bayesiano. Revista Brasileira de Zootecnia, v.39, p.2426-2433, 2010. DOI: https://doi.org/10.1590/S1516-35982010001100015.

PEDROSA, V.B.; ELER, J.P.; FERRAZ, J.B.S.; PINTO, L.F.B. Utilização de modelos unicaracterística e multicaracterística na estimação de parâmetros genéticos na raça Nelore. Arquivo Brasileiro de Medicina Veterinária e Zootecnia, v.66, p.18021812, 2014. DOI: https://doi.org/10.1590/1678-6170.

PETERS, S.O.; KIZILKAYA, K.; GARRICK, D.J.; FERNANDO, R.L.; POLLAK, E.J.; ENNS, R.M.; DONATO, M. de; AJAYI, O.O.; IMUMORIN, I.G. Use of robust multivariate linear mixed models for estimation of genetic parameters for carcass traits in beef cattle. Journal of Animal Breeding and Genetics, v.131, p.504-512, 2014. DOI: https://doi.org/10.1111/jbg.12093.
PIMENTEL, E. da C.G.; QUEIROZ, S.A. de; CARVALHEIRO, R.; FRIES, L.A. Estimativas de efeitos genéticos em bezerros cruzados por diferentes modelos e métodos de estimação. Revista Brasileira de Zootecnia, p.1020-1027, 2006. DOI: https://doi. org/10.1590/S1516-35982006000400012.

R CORE TEAM. R: a language and environment for statistical computing. Vienna: R Foundation for Statistical Computing, 2013.

ROSO, V.M.; SCHENKEL, F.S. AMC - a computer programme to assess the degree of connectedness among contemporary groups. In: WORLD CONGRESS ON GENETICS APPLIED TO LIVESTOCK PRODUCTION, 8., 2006, Belo Horizonte. Proceedings. Belo Horizonte: Instituto Prociência, 2006.

SMITH, B.J. boa: an R package for MCMC output convergence assessment and posterior inference. Journal of Statistical Software, v.21, p.1-37, 2007.

SPIEGELHALTER, D.J.; BEST, N.G.; CARLIN, B.P.; LINDE, A. VAN DER. Bayesian measures of model complexity and fit. Journal of the Royal Statistical Society: Series B (Statistical Methodology), v.64, p.583-639, 2002. DOI: https://doi. org/10.1111/1467-9868.00353.

TORAL, F.L.B.; TORRES JÚNIOR, R.A. de A.; LOPES, P.S.; CARDOSO, F.F.; SILVA, L.O.C. da. Heteroskedasticity for weaning weight of Charolais-Zebu crossbred calves. Revista Brasileira de Zootecnia, v.41, p.1163-1172, 2012. DOI: https:// doi.org/10.1590/S1516-35982012000500013.

VAN MELIS, M.H.; ELER, J.P.; SILVA, J.A. II de V.; FERRAZ, J.B.S. Estimação de parâmetros genéticos em bovinos de corte utilizando os métodos de máxima verossimilhança restrita e Â. Revista Brasileira de Zootecnia, v.32, p.16241632, 2003. Supl. 1. DOI: https://doi.org/10.1590/S151635982003000700011.

WILLIAMS, J.L.; AGUILAR, I.; REKAYA, R.; BERTRAND, J.K. Estimation of breed and heterosis effects for growth and carcass traits in cattle using published crossbreeding studies. Journal of Animal Science, v.88, p.460-466, 2010. DOI: https:// doi.org/10.2527/jas.2008-1628. 